\title{
KOREKSI UKURAN MATA PANCING RAWAI TEGAK UNTUK MENANGKAP IKAN PELAGIS KECIL DI PERAIRAN SELAT SEMAU
}

\section{CORRECTION OF HOOK SIZE OF VERTICAL LONGLINE TO CATCH SMALL PELAGIC FISHES IN SEMAU STRAIT}

\author{
Ricky Winrison Fuah ${ }^{1 \#}$, Diniah ${ }^{2}$ dan Gondo Puspito ${ }^{2}$ \\ ${ }^{1}$ Program Studi Teknologi Perikanan Laut, Sekolah Pascasarjana, Institut Pertanian Bogor \\ ${ }^{2}$ Departemen Pemanfaatan Sumberdaya Perikanan \\ Fakultas Perikanan dan Ilmu Kelautan, Institut Pertanian Bogor \\ E-mail: rickywinrisonfuah@gmail.com
}

(Diterima: 12 Maret 2019; Diterima setelah perbaikan: 24 Juli 2019; Disetujui: 25 Juli 2019)

\begin{abstract}
ABSTRAK
Alat tangkap yang digunakan untuk menangkap ikan pelagis kecil di perairan Selat Semau yaitu rawai tegak. Operasi penangkapanikan menggunakan ukuran mata pancing nomor 18, 16 dan 15. Tujuan penelitian yaitu untuk menentukan ukuran mata pancing yang tepat dalam menangkap ikan pelagis kecil yang layak tangkap. Metode penelitian yang digunakan adalah experimentalfishing, dengan metode analisis data uji normalitas Kolmogorov-Smirnov, uji Kruskal Wallis dan uji Mann-Whitney. Jumlah responden 12 orang. Hasil penelitian diperoleh presentase ukuran ikan tidak layak tangkap 65\%-72\% dan layak tangkap 28\%-34\% (nomor 18), tidak layak tangkap 26\%-33\% dan layak tangkap 67\%-74\% (nomor 16), tidak layak tangkap 23\%-36\% dan 64\%-74\% layak tangkap (nomor 15). Kesimpulannya adalah ukuran mata pancing nomor 16 dan 15 lebih tepat untuk menangkap ikan pelagis kecil layak tangkap. Saran yang dapat diberikan adalah perlu dilakukan penelitian tentang pengamatan gonad ikan sehingga dapat membuktikan mata pancing nomor 16 dan 15 menangkap ikan layak tangkap.
\end{abstract}

KATA KUNCI: Pelagis kecil; rawai tegak; ukuran mata pancing; Selat Semau

\begin{abstract}
Fishing gear used to catch small pelagic fish in the Semau strait water, namely vertical longline. Fishing operations use difference hook size, number 18, 16 and 15. The purpose of the study is to determine the size of the right hook size to cacthing small pelagic fish in legal size. Method the research used was experimental fishing, with the method of analyzing the Kolmogorov-Smirnov normality test, the Kruskal Wallis test and the Mann-Whitney test. The number of respondents is 12 people. The result obtained a percentage of the size of fish illegal size 65\%-72\% and legal size 28\%-34\% (number 18), illegal size 26\%-33\% and legal size 67\%-74\% (number 16), illegal size 23\%-36\% and legal size 64\%-74\% (number 15). The conclusion is the hook size of number 16 and 15 more appropriate for catching small pelagic fish legal size. Recommanded that can be given is that it is necessary to do research on observing gonads of fish so that they can prove hook size number 16 and 15 catching fish of legal size.
\end{abstract}

KEYWORDS: Pelagic fish; vertical longline; hook size; Semau strait

\footnotetext{
\# Korespondensi: Program Studi Teknologi Perikanan Laut, Sekolah Pascasarjana, Intitut Pertanian Bogor

E-mail: rickywinrisonfuah@gmail.com
} 


\section{PENDAHULUAN}

Ikan pelagis kecil merupakan sumberdaya yang tergolong dalam "poorly behaved" karena makanan utamanya adalah plankton, sehingga kelimpahannya bergantung pada faktor-faktor lingkungan (Merta et al., 1998). Di Nusa Tenggara Timur sumberdaya pealgis kecil hampir ditemui pada seluruh perairansalah satunya adalah perairan Selat Semau (Kause et al., 2013). Menurut Ataupah (2010), Ikan pelagis kecil di Selat Semau yang dominan adalah ikan layang (Decapterus sp), ikan selar (Selaroides sp), ikan kembung (Rastrelliger faughni), ikan teri (Stolephorus commersoni) dan ikan tembang (Sardinella fimrbiata). Pemanfaatan ikan pelagis kecil di Selat Semau dilakukan oleh berbagai nelayan baik itu nelayan dari kota Kupang maupun nelayan Tablolong. Salah satu alat tangkap yang digunakan adalah rawai tegak (vertical longline).

Rawai tegak (vertical longline) adalah satu jenis alat penangkapan ikan yang menggunakan mata pancing dengan atau tanpa umpan (Sadhori,1984). Mata pancing dikaitkan pada tali pancing dan dioperasikan menggunakan tenaga manusia (Sudirman \&Mallawa,2012). Selain itu konstruksinya sangat sederhana dan pengoperasiannya juga tidak memerlukan modal yang besar (Ardidja, 2011). Konstruksi rawai tegak (vertical longline) terdiri dari satu tali utama dan beberapa tali cabang yang dipasangi sejumlah mata pancing. Mata pancing dipasang langsung pada tali cabang yang diikatkan pada tali utama. Menurut Puspito (2009), Pengoperasian alat penangkapan ikan rawai tegak dengan cara menurunkannya ke dalam perairan dimulai dari tali utama, tali cabang dan sejumlah mata pancing yang sudah diberi umpan, baik itu umpan alami maupun umpan buatan.

Faktor utama dalam keberhasilan pengoperasian alat tangkap rawai tegak adalah ukuran dan bentuk mata pancing serta berbagai jenis umpan baik umpan alami maupun umpan buatan (Kurnia et al., 2015). Ukuran mata pancing sangat mempengaruhi besar kecilnya ukuran ikan yang tertangkap. Menurut Alos et al. (2008), Ukuran ikan target yang tertangkap menggunakan alat tangkap pancing akan cenderung mengikuti ukuran mata pancing yang digunakan.

Ukuran mata pancing yang digunakan oleh nelayan Tablolong untuk menangkap ikan pelagis kecil memiliki ukuran yang relatif kecil yaitu nomor 18, sehingga hasil tangkapan yang diperoleh cenderung memiliki ukuran yang relatif kecil pula (tidak layak tangkap). Hal ini diprediksi akan sangat mengganggu keberlangsungan sumberdaya ikan pelagis kecil yang ada di selat Semau. Menurut Sadhotomo \& Atmaja
(2012) jika ukuran ikan yang tidak layak tangkap secara terus menerus ditangkap maka kemampuan ikan untuk berkembang menjadi ikan dewasa tidak akan terjadi, sehingga akan menyebabkan jumlah stok ikan yang ada disuatu perairan akan menurun. Peristiwa tersebut akan berdampak pada jumlah hasil tangkapan yang diperoleh semakin sedikit sehingga pendapatan dari nelayan pun akan ikut menurun.

Penanggulangan permasalahan di atas merupakan hal yang wajib dilakukan sehingga keberlangsungan sumberdaya ikan pelagis kecil akan selalu terjaga. Salah satunya adalah dengan melakukan koreksi dan uji coba terhadap ukuran mata pancing yang digunakan nelayan. Oleh karena itu, dalam penelitian ini akan dilakukan uji coba ukuran mata pancing yang berbeda, dengan tujuan untuk menentukan ukuran mata pancing yang tepat dalam menangkap ikan pelagis kecil.

\section{BAHAN DAN METODE}

Penelitian dilakukan langsung di perairan Selat Semau, Kabupaten Kupang, Nusa Tenggara Timur (Gambar 1) menggunakan metode experimental fishing. Pengoperasin rawai tegak dilakukan selama 7 hari pada bulan September 2018. Satu trip berlangsung 1 hari, setiap trip dilakukan beberapa kali setting dan hauling yang dimulai dari pukul 09.00-15.00 WITA. Rawai tegak yang digunakan berjumlah 12 unit terdiri atas 4 unit rawai tegak menggunakan mata pancing nomor 18 (kontrol), 4 unit menggunakan mata pancing nomor 16, dan 4 unit menggunakan mata pancing nomor 15. Setiap unit alat tangkap dilengkapi dengan jenis (karet pentil dan kain kaca) dan warna umpan buatan (merah dan kuning).

Rawai tegak yang digunakan memiliki bagianbagian antara lain tali utama (main line) dengan panjang $150 \mathrm{~m}$, tali cabang (branch line) dengan panjang 30 $\mathrm{cm}$. Jarak pemasangan antar tali cabang adalah 150 $\mathrm{cm}$. Dalam satu tali utama terdiri dari 20 tali cabang yang ujungnya diberi mata pancing. Mata pancing yang digunakan adalah mata pancing biasa ( $h o o k)$ nomor 18, 16 dan 15. Jumlah mata pancing pada satu unit rawai yaitu 20 mata pancing. Setiap mata pancing dipasang umpan buatan karet pentil dan kain kaca. Terakhir kili-kili (swivel) dan pemberat (sinker).

Kegiatan pemancingan menggunakan satu unit kapal dengan ukuran $(14,50 \mathrm{~m}$ x 1,42 m x 1,30 m) dan 12 orang nelayan, setiap nelayan mengoperasikan masing-masing alat tangkap yaitu 1 unit. Jarak antara nelayan satu dengan yang lain adalah $1 \mathrm{~m}$ pada setiap sisi kapal baik sisi kanan kapal maupun sisi kiri kapal dari bagian haluan sampai buritan. Nelayan yang mengoperasikan alat tangkap merupakan nelayan yang sangat berpengalaman dalam mengoperasikan rawai 
tegak. Posisi dari nelayan diatas kapal dapat ditunjukan pada Gambar 3.

Prosedur perlakuan eksperimentalfishing rawai tegak terdiri dari beberapa tahap diantaranya:

(1) Setiap nelayan menggunakan satu unit alat tangkap, (2) Operasi penangkapan dilakukan dari pukul 09.00-15.00 WITA (6 jam operasi/trip), (3) Waktu digunakan sebagai ulangan, (4) Setiap 30 menit dianggap sebagai penanda pergantian ulangan (12 kali ulangan/trip), dan (5) Posisi pemancing dipertukarkan setiap harinya.

Ikan hasil tangkapan akan digolongkan berdasarkan ukuran mata pancing dan jenis umpan. Selanjutnya akan dilakukan pengukuran panjang ikan hasil tangkapan (Sparre \& Venema, 1998) dengan cara mengukur panjang dimulai dari ujung mulut ikan ke ujung ekor (TL) menggunakan penggaris setiap 30 menit sekali.

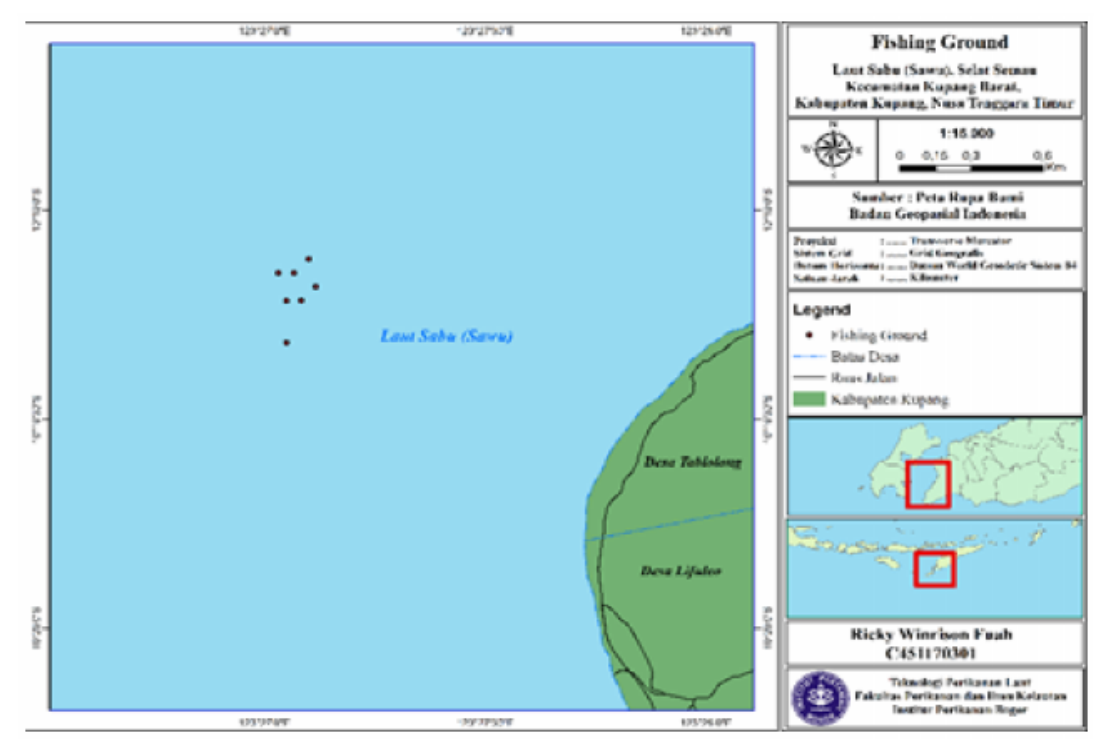

Gambar 1. Peta laut daerah penangkapan.

Figure 1. Map of the fishing ground.

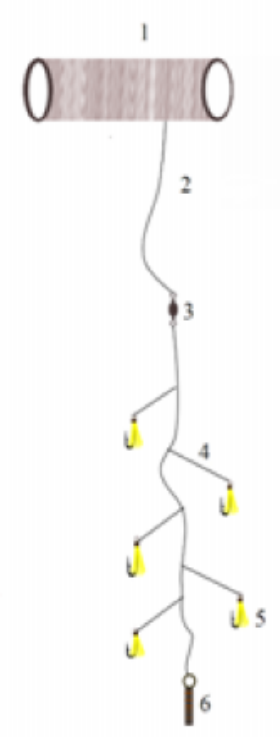

Keterangan:

1. Penggulung

2. Tali Utama

3. Kili-kili

4. Tali Cabang

5. Pancing dan Umpan

6. Pemberat

Gambar 2. Konstruksi dan spesifikasi rawai tegak.

Figure 2. Construction and specifications of vertical longline. 


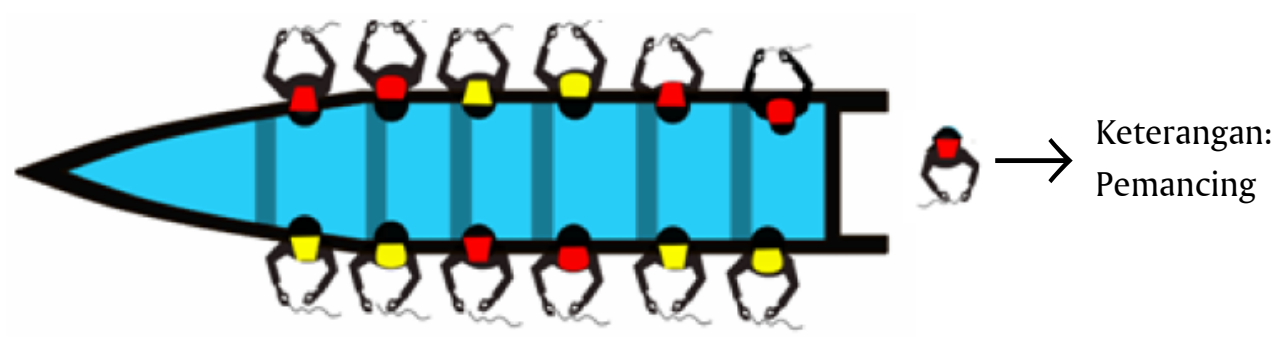

Gambar 3. Posisi pemancing di atas kapal.

Figure 3. Position of the fisherman on the boat.

Pada penelitian ini, hipotesis yang dapat dirumuskan berdasarkan permasalahan di atas yaitu ukuran mata pancing mempengaruhi ukuran ikan layak tangkap.

Data hasil tangkapan yang dikumpulkan berupa jumlah hasil tangkapan dan panjang ikan. Selanjutnya akan diplotkan dalam bentuk diagram dan dibandingkan berdasarkan jenis ukuran mata pancing. Selanjutnya data dianalisis menggunakan uji statistik non parametrik untuk mengetahui pengaruh ukuran mata pancing terhadap ikan hasil tangkapan (layak tangkap) mengacu pada studi literatur. Tahapannya dimulai dari uji normalitas Kolmogorov-Smirnov, uji Kruskal Wallis dan uji Mann-Whitney (Supangat, 2008; Usman \& Akbar, 2008).

\section{HASIL DAN PEMBAHASAN}

\section{Komposisi Hasil Tangkapan}

Hasil tangkapan yang diperoleh selama uji coba penangkapan ikan dengan menggunakan rawai tegak merupakan ikan pelagis kecil yang memiliki ekonomis penting. Spesies yang tertangkap adalah 5 spesies yaitu ikan kembung (Rastrelliger faughni), selar bentong (Selar crumenophthalmus), layang
(Decapterus russelli), layang ekor merah (Decapterus $t a b l)$, dan selar kuning (Selaroides leptolepis). Jumlah total keseluruhan hasil tangkapan untuk semua spesies yang tertangkap yaitu 10.285 ekor dengan berat keseleruhan $572 \mathrm{~kg}$. Hasil tangkapan tersebut terbagi menjadi hasil tangkapan mata pancing nomor 18 yaitu 3.379 ekor dengan berat $187,72 \mathrm{~kg}$, mata pancing nomor 16 yaitu 3.458 ekor dengan berat $192,88 \mathrm{~kg}$, dan mata pancing nomor 15 yaitu 3.448 ekor dengan berat 191,36 kg.

Berdasarkan spesies yang ditangkap, jumlah terbanyak yaitu ikan selar bentong sebanyak 3072 ekor dimana tertangkap terbanyak menggunakan pancing nomor 16 dengan menggunakan umpan karet pentil warna merah yaitu 326 ekor dan tertangkap sedikit menggunakan pancing nomor 15 dengan menggunakan umpan kain kaca warna kuning yaitu 200 ekor, sedangkan spesies yang tertangkap paling sedikit yaitu ikan layang ekor merah yaitu 1645 ekor dimana tertangkap terbanyak menggunakan pancing nomor 18 dengan menggunakan umpan karet pentil warna merah yaitu 168 ekor dan yang tertangkap sedikit menggunakan pancing nomor 15 dengan menggunakan umpan kain kaca warna kuning yaitu 106 ekor. Lebih detainya dapat dilihat pada Tabel 1, 2 dan 3 .

Tabel 1. Hasil tangkapan berdasarkan ukuran mata pancing 18

Table 1. Catch based on the size of hook 18

\begin{tabular}{|c|c|c|c|c|c|c|}
\hline \multirow{3}{*}{$\mathrm{No}$} & \multirow{3}{*}{ Spesies } & \multicolumn{4}{|c|}{ Ukuran mata pancing 18} & \multirow{3}{*}{ Total } \\
\hline & & \multicolumn{2}{|c|}{$\mathrm{K}$ aret $\mathrm{Pentil}$} & \multicolumn{2}{|c|}{$\mathrm{K}$ ain $\mathrm{K}$ aca } & \\
\hline & & Merah & $\mathrm{K}$ uning & Merah & $\mathrm{K}$ uning & \\
\hline 1 & Kembung & 85 & 78 & 205 & 212 & 580 \\
\hline 2 & Selar Bentong & 302 & 275 & 207 & 217 & 1001 \\
\hline 3 & Lay ang & 167 & 167 & 121 & 121 & 576 \\
\hline 4 & Layang Ekor Merah & 168 & 157 & 113 & 116 & 554 \\
\hline 5 & Selar Kuning & 217 & 214 & 119 & 118 & 668 \\
\hline & Total & 939 & 891 & 765 & 784 & 3379 \\
\hline
\end{tabular}


Tabel 2. Hasil tangkapan berdasarkan ukuran mata pancing 16

Table 2. Catch based on the size of hook 16

\begin{tabular}{|c|c|c|c|c|c|c|}
\hline \multirow{3}{*}{$\mathrm{No}$} & \multirow{3}{*}{ Spesies } & \multicolumn{4}{|c|}{ Ukuran mata pancing 16} & \multirow{3}{*}{ Total } \\
\hline & & \multicolumn{2}{|c|}{$\mathrm{K}$ aret $\mathrm{Pentil}$} & \multicolumn{2}{|c|}{$\mathrm{K}$ ain $\mathrm{K}$ ac a } & \\
\hline & & Merah & Kuning & Merah & $\mathrm{Kuning}$ & \\
\hline 1 & Kem bung & 100 & 85 & 215 & 220 & 620 \\
\hline 2 & Selar Bentong & 326 & 292 & 213 & 214 & 1045 \\
\hline 3 & Lay ang & 165 & 160 & 111 & 120 & 556 \\
\hline 4 & Layang Ekor Merah & 163 & 160 & 113 & 111 & 547 \\
\hline 5 & Selar Kuning & 223 & 217 & 119 & 131 & 690 \\
\hline & Total & 977 & 914 & 771 & 796 & 3458 \\
\hline
\end{tabular}

Tabel 3. Hasil tangkapan berdasarkan ukuran mata pancing 15

Table 3. Catch based on the size of hook 15

\begin{tabular}{|c|c|c|c|c|c|c|}
\hline \multirow{3}{*}{$\mathrm{No}$} & \multirow{3}{*}{ Spesies } & \multicolumn{4}{|c|}{ Ukuran mata pancing 15} & \multirow{3}{*}{ Total } \\
\hline & & \multicolumn{2}{|c|}{$\mathrm{K}$ aret $\mathrm{Pentil}$} & \multicolumn{2}{|c|}{$\mathrm{K}$ ain $\mathrm{K}$ aca } & \\
\hline & & M erah & Kuning & Merah & Kuning & \\
\hline 1 & K embung & 107 & 81 & 225 & 218 & 631 \\
\hline 2 & Selar Bentong & 322 & 296 & 208 & 200 & 1026 \\
\hline 3 & La y ang & 171 & 161 & 114 & 104 & 550 \\
\hline 4 & Layang Ekor Merah & 165 & 160 & 113 & 106 & 544 \\
\hline 5 & Selar Kuning & 224 & 216 & 119 & 138 & 697 \\
\hline & Total & 989 & 914 & 779 & 766 & 3448 \\
\hline
\end{tabular}

\section{Komposisi Berdasarkan Ukuran Ikan}

Berdasarkan penelitian, diperoleh ukuran ikan hasil tangkapan sangat beragam menurut spesies yang tertangkap. Ikan kembung memiliki kisaran ukuran 14-28 cm, selar bentong memiliki kisaran ukuran 10$30 \mathrm{~cm}$, layang memiliki kisaran ukuran $12-25 \mathrm{~cm}$, layang ekor merah memiliki kisaran ukuran $13-29 \mathrm{~cm}$ dan selar kuning memiliki kisaran ukuran $12-22 \mathrm{~cm}$. Semua spesies yang tertangkap menggunakan mata pancing nomor 18 memiliki presentase ukuran tidak layak tangkap lebih besar dari pada ukuran layak tangkap, dengan presentase 65\%-72\% untuk tidak layak tangkap dan 28\%-34\% layak tangkap, sedangkan presentase ukuran ikan tidak layak tangkap dan layak tangkap pada mata pancing nomor 16 dan 15 berbanding terbalik dengan nomor 18 , yaitu nomor 16 presentese tidak layak tangkap 26\%-33\% dan layak tangkap 67\%-74\%. Hal ini pun terlihat pada mata pancing nomor 15 dengan presentase tidak layak tangkap lebih sedikit dari pada layak tangkap, yaitu 23\%-36\% tidak layak tangkap dan 64\%-74\% layak tangkap. Sebaran presentase ukuran ikan target dapat dilihat pada Tabel 4.

\section{Uji Normalitas}

Berdasarkan data yang telah diuji menggunakan One-Sample Kolmogorov-Smirnov Test dari hipotesis yang ada menunjukkan nilai signifikansi KolmogorovSmirnovuntuk perlakuan ukuran mata pancing sebesar 0,000 . Nilai ini berada di bawah atau lebih kecil dari taraf signifikansi 0,05, maka dapat disimpulkan bahwa data hasil tangkapan untuk perlakuan mempunyai sebaran data yang tidak normal. Hal ini mengacu pada pengambilan keputusan yang ada pada metode Kolmogorov-Smirnov dimana jika Asymp. Sig < 0,05 maka sebaran data tersebut tidak normal sedangkan jika Asymp. Sig > 0,05 maka sebaran data tersebut normal (Usman \& Akbar, 2008). Setelah pengujian kenormalan data selesai, karena data tersebut tidak berdistribusi dengan normal maka untuk melakukan analisis datanya menggunakan analisis non-parametrik dalam hal ini menggunakan uji Kruskal Wallis dan uji Mann-Whitney. 
Tabel 4. Presentase ukuran ikan target menurut mata pancing Table 4 . The percentage of the target fish according to the hooks

\begin{tabular}{|c|c|c|c|c|c|c|c|}
\hline \multirow{3}{*}{$\mathrm{No}$} & \multirow{3}{*}{ Spesies } & \multicolumn{6}{|c|}{ Ukuran ikan target menurut mata pancing } \\
\hline & & \multicolumn{2}{|c|}{18} & \multicolumn{2}{|c|}{16} & \multicolumn{2}{|c|}{15} \\
\hline & & $\begin{array}{c}\text { TL T } \\
(\%)\end{array}$ & $\begin{array}{c}\mathrm{L} \mathrm{T} \\
(\%)\end{array}$ & $\begin{array}{l}\text { TL T } \\
(\%)\end{array}$ & $\begin{array}{l}\mathrm{LT} \\
(\%)\end{array}$ & $\begin{array}{c}\mathrm{TLT} \\
(\%)\end{array}$ & $\begin{array}{l}\mathrm{LT} \\
(\%)\end{array}$ \\
\hline 1 & Kembung & 65 & 35 & 27 & 73 & 29 & 71 \\
\hline 2 & Selar B entong & 71 & 29 & 26 & 74 & 23 & 77 \\
\hline 3 & Lay ang & 67 & 33 & 27 & 73 & 26 & 74 \\
\hline 4 & Layang Ekor M erah & 66 & 34 & 28 & 72 & 34 & 66 \\
\hline 5 & Selar Kuning & 72 & 28 & 33 & 67 & 36 & 64 \\
\hline
\end{tabular}

Keterangan:

$$
\begin{array}{ll}
\text { TLT } & \text { : Tidak Layak Tangkap (Illegal size) } \\
\text { LT } & \text { : Layak Tangkap (legal size) }
\end{array}
$$

\section{Pengaruh ukuran mata pancing terhadap ukuran ikan layak tangkap}

Faktor-faktor yang mempengaruhi efisiensi suatu alat tangkap ikan merupakan juga faktor-faktor yang mempengaruhi keberhasilan operasi penangkapan ikan. Faktor tersebut tidaklah dapat dipisahkan antara satu dengan yang lain karena masing-masing saling berkaitan secara erat sekali. Salah satu faktor yang berpengaruh penting dalam tertangkapnya ikan yang layak tangkap adalah ukuran dari mata pancing itu sendiri.

Pada penelitian yang telah dilakukan, jumlah hasil tangkapan yang diperoleh menurut ukuran mata pancing tidak terlalu memiliki perbedaan yang sangat signifikan. Hasil tangkapan yang diperoleh menggunakan mata pancing nomor 18 (kontrol) yaitu 3.379 ekor, jika dibandingkan menggunakan mata pancing rekonstruksi yaitu nomor 16 sebanyak 3.458 ekor dan nomor 15 sebanyak 3.448 ekor. Namun jika dilihat dari ukuran ikan yang tertangkap untuk semua spesies, mata pancing nomor 18 memiliki perbedaan yang sangat signifikan dari mata pancing 16 dan 15 . Hal ini berbanding lurus menurut penelitian Cooke et al. Philipp (2005), dan Zaragoza et al. (1989),yang menyatakan bahwa ukuran mata pancing tidak berpengaruh secara langsung terhadap jumlah hasil tangkapan melainkan ukuran hasil tangkapan.

Berdasarkan hasil uji Kruskal Wallis diperoleh nilai Asymp. Sig < 0,05 untuk semua spesies yang tertangkap, berarti bahwa ada pengaruh dari penggunaan ukuran mata pancing yang berbeda terhadap ukuran ikan yang layak tangkap. Hal ini mengacu dari pengambilan keputusan yang ada pada metode Kruskal Wallis dimana jika Asymp. Sig $<0,05$ maka ada perbedaan sedangkan jika Asymp. Sig $>$
0,05 maka tidak ada perbedaan (Usman \& Akbar, 2008). Setelah dilakukan analisis uji Kruskal Wallis dan mendapatkan adanya pengaruh, maka analisis lanjutannya menggunakan uji Mann-Whitney untuk melihat apakah ada perbedaan dalam penggunaan ketiga ukuran pancing tersebut terhadap ikan yang layak tangkap.

Dari hasil uji Mann-Whitney dapat disimpulkan bahwa 5 spesies yang ditangkap menggunakan ukuran pancing 18 memiliki perbedaan dari ukuran 16 dan 15, dimana dapat dilihat pada nilai Asymp. Sig < 0,05. Sedangkan antara pancing nomor 16 dan 15 tidak memiliki perbedaan dari ukuran ikan yang ditangkap untuk 5 spesies tersebut. Hal ini dapat dilihat dari nilai Asymp. Sig $>0,05$. Oleh karena itu dapat ditarik kesimpulan bahwa pancing nomor 18 relatif menangkap ikan yang tidak layak tangkap (illegal size) untuk 5 spesies yang tertangkap jika dibandingkan dengan menggunakan pancing nomor 16 dan 15 . Kedua nomor pancing perlakuan tersebut dapat menangkap 5 spesies tersebut yang termasuk dalam golongan ikan layak tangkap (legal size).

Tertangkapnya ikan pelagis kecil yang layak tangkap dengan menggunakan mata pancing nomor 16 dan 15 dikarenakan ukuran mata pancing tersebut lebih besar dari pada nomor 18. Ukuran layak tangkap dari ikan target diantaranya ikan kembung yaitu 20,1 cm (Bubun \& Mahmud, 2015), ikan selar bentong yaitu 17,6 cm (Sangadji, 2014, p.48), ikan selar kuning, yaitu 16,2 cm (Supeni \&Almohdar, 2017), ikan layang yaitu 16,8 cm (Ongkers et al., 2016) dan ikan layang ekor merah yaitu 19,7 (Fishbase, 2018). Selain itu, kedua ukuran pancing tersebut juga digunakan karena mengacu pada ukuran bukaan mulut dari ikan target. Ukuran dari bukaan mulut ikan sangat mempengaruhi ikan untuk menerkam atau memakan mata pancing dan akan 
memudahkan mata pancing tertelan atau tersangkut didalam mulut (Kurnia et al., 2015).

Ukuran bukaan mulut yang diperoleh dari penelitian, untuk setiap spesies yang tertangkap memiliki ukuran bukaan mulut antara lain; ikan selar bentong 1,2-2,0 cm, ikan kembung 2,0-3,0 cm, ikan layang $0,8-1,5 \mathrm{~cm}$, ikan layang ekor merah $1,0-2,0 \mathrm{~cm}$ dan ikan selar kuning 0,8-2,0 cm. Berdasarkan ukuran bukaan mulut yang diperoleh untuk spesies target, pancing nomor 16 dan 15 memiliki ukuran yang lebih cocok atau tepat untuk menangkap ikan pelagis kecil yang layak tangkap. Hasil penelitian yang sama terkait dengan bukaan mulut ikan, diperoleh oleh Karpouzi \& Stergiou (2003), dimana Ukuran bukaan mulut ikan menjadi faktor penting yang mempengaruhi ukuran hasil tangkapan pancing ulur.

\section{KESIMPULAN DAN SARAN}

Ukuran ikan target yang tertangkap menggunakan mata pancing nomor 18 lebih banyak tergolong tidak layak tangkap jika dibandingkan dengan mata pancing nomor 16 dan 15 , dengan presentase $65 \%-72 \%$ tidak layak tangkap dan 28\%-34\% layak tangkap, sebaliknya nomor 16 presentese tidak layak tangkap 26\%-33\% dan layak tangkap 67\%-74\% dan nomor 15 presentase tidak layak tangkap 23\%-36\% dan 64\%-74\% layak tangkap. Ukuran mata pancing yang tepat digunakan untuk menangkap ikan layak tangkap adalah ukuran mata pancing nomor 15 dan 16.

Perlu adanya penelitian mengenai identifikasi gonad pada ikan hasil tangkapan dengan tujuan dapat membandingkan antara ukuran panjang ikan dan bentuk gonad agar dapat menentukan apakah ikan yang ditangkap menggunakan mata pancing 16 dan 15 merupakan ikan layak tangkap.

\section{DAFTAR PUSTAKA}

Alos, J., Palmer, M., Grau, A.M., \&Deudero, S. (2008). Effects of Hook Size and Barbless Hooks on Hooking Injury, Catch Per Unit Effort, and Fish Size in a Mixed-Species Recreational Fishery in the Western Mediterranean Sea. ICES Journal of Marine Science, 65,899-905.

Ataupah, A.E,. (2010). Penangkapan Ikan Kakap (Lutjanus sp) Di Kabupaten Kupang Propinsi Nusa Tenggara Timur. [Skripsi] Jurusan Pemanfaatan Sumberdaya Perikanan. Fakultas Perikanan dan Ilmu Kelautan. Institut Pertanian Bogor. Hal 37.

Ardidja, S. (2011). Usaha Penangkapan Ikan dengan Pancing Tegak. Materi Penyuluhan Perikanan. Kementerian Kelautan dan Perikanan, Badan Pengembangan Sumberdaya Manusia Kelautan dan Perikanan, Pusat Penyuluhan Kelautan dan Perikanan. Jakarta.
Bubun, R.L., \&Mahmud, A. (2015). Komposisi Hasil Tangkapan Pukat Cincin Hubungannya dengan Teknologi Penangkapan Ikan Ramah Lingkungan. Marine Fisheries, 6(2),177-186.

Cooke, S.J., Barthel, B.L., Suski, C.D., Siepker, M.J., \& Philipp, D.P. (2005). Influence of Circle Hook Size on Hooking Efficiency, Injury, and Size Selectivity of Bluegill with Comments on Circle Hook Conservation Benefits in Recreational Fisheries, North American Journal of Fisheries Management, 25:211-219.

Karpouzi, V.S., \&Stergiou, K.I. (2003). The Relationships Between Mouth Size and Shape and Body Length for 18 Species of Marine Fishes and their Trophic Implications. Journal of Fish Biology, 62:1353-1365.

Kause, W.L., Heltiarne, M.R., Komba, Y.T., Salim,A., \& Djesse, S.T. (2013). Kajian Status Provinsi Nusa Tenggara Timur Sebagai Provinsi Kepulauan Ditinjau Dari Perspektif Hukum. Jurnal Borneo Administrator, 9(2),137-161.

Kurnia, M., Sudirman, \& Yusuf, M. (2015). Pengaruh Perbedaan Ukuran Mata Pancing Terhadap Hasil Tangkapan Pancing Ulur Di Perairan Pulau Sabutung Pangkep. Marine Fisheries,6(1),87-95.

Merta, Saksono, A., \& Suyedi, R. (1998). Penyebaran Ikan Pelagis di Indonesia. Bogor: Fakultas Perikanan IPB.

Ongkers, O.T.S., Pattikawa, J.A., \& Rijoly, F. (2016). Aspek biologi Ikan Layang (Decapterus ruselli) di Perairan Latuhalat, Kecamatan Nusaniwe, Pulau Ambon. Omni Akuatika, 12(3),79-87.

Puspito, G. (2009). Pancing. Buku Ajar. Departemen Pemanfaatan Sumberdaya Perikanan Fakultas Perikanan dan Ilmu Kelautan Institut Pertanian Bogor: Bogor.

Sadhori, N. (1984). Teknik Penangkapan Ikan. Bandung: Angkasa.

Sadhotomo, B., \& Atmaja, S. B. (2012). Sintesa Kajian Stok Ikan Pelagis Kecil di Laut Jawa. Jurnal Penelitian dan Perikanan Indonesia, 18(4),221-232.

Sangadji, M. (2014). Biologi Ikan Selar (Selar crumenophthalmus Bloch, 1973) di Perairan Selat Haruku Kab. Maluku Tengah. Jurnal Ilmiah Agribisnis dan Perikanan, 7(2),46-50.

Sparre, P., \& Venema, S.C. (1998). Introduksi Pengkajian Stok Ikan Tropis Buku e-manual (Edisi Terjemahan). Kerjasama Organisasi Pangan, Perserikatan Bangsa-Bangsa dengan Pusat Penelitian dan Pengembangan Perikanan, Badan Penelitian dan Pengembangan Pertanian. Jakarta.

Sudirman, \& Mallawa. (2012). Teknik Penangkapan Ikan. Jakarta: Rineka Cipta.

Supangat, A. (2008). Statistika: Dalam Kajian 
Deskriptif, Inferensi, dan Nonparametrik. Jakarta: Kencana Prenada Media Group.

Supeni, E.A., \& Almohdar, E. (2017). Pola Pertumbuhan Ikan Selar (Selaroides leptolepis) di Perairan Kabupaten Maluku Tenggara. Fish Scientiae, $7(2), 105-112$.

Usman, H., \& Akbar, P.S. (2008). Pengantar Statistika Edisi Kedua. Jakarta: Bumi Aksara.
www.Fishbase.org. 2018. Species Summary. [20 Mei 2018].

Zaragoza, C. E., Dalzell, P., \& Pauly, D. (1989). Hook selectivity of Yellowfin Tuna (Thunnus albacares) Caught off Darigayos Cove, La Union, Philippines. Journal of Applied Ichthyology, 5,12-17. 